\title{
CINE DE COMPILACIÓN Y ESCRITURA HISTÓRICA: EL CASO DE LA SPIRALE*
}

\section{Tomás Cornejo C.**}

\section{Resumen}

Indagación sobre el cine de compilación y sus similitudes y diferencias con el discurso sobre el pasado escrito por los historiadores. Desde la constatación del uso de imágenes de archivo y su reutilización en nuevas cintas de carácter documental, se establece una correspondencia entre la operación de montaje fílmico y la historiografía. La reflexión está guiada por el análisis del documental La Spirale (1976), producción francesa co-dirigida por Armand Mattelart bajo la inspiración de Chris Marker sobre la caída de la Unidad Popular chilena.

Palabras clave: cine de compilación, La Spirale, documental, escritura histórica.

\section{FILM COMPILATION AND HISTORICAL WRITING: THE CASE OF LA SPIRALE}

\begin{abstract}
Inquiry on the compilation film and its similarities and differences with the discourse about past written by historians. Stressing the use of found footage and secuences from archives and its reuse in new documentary films, a correspondence between the editing operation and historiography is established. The reflection is guided by the analysis of the documentary La Spirale (1976), French production co-directed by Armand Mattelart under the inspiration of Chris Marker, about the fall of the Chilean Popular Unity government.
\end{abstract}

Keywords: compilation film, La Spirale, documentary film, historical writing.

* Este artículo es un producto de investigación que surge en el marco del proyecto Tradición e innovación en la literatura hispánica del grupo de investigación de estudios literarios del contexto social hispánico de la Universidad Nacional de Colombia, Departamento de Lenguas.

** Chileno. Doctor en Historia, El Colegio de México, México. Académico Escuela de Historia Universidad Diego Portales, Santiago, Chile. tomas.cornejo@mail.udp.cl 


\section{Introducción:}

\section{Una modalidad cinematográfica cercana}

Este texto forma parte de un campo de problemas mayor cuya exploración ha ido desarrollándose en los últimos años: la capacidad del cine para representar el pasado y conferir a determinadas secuencias de imágenes en movimiento que aluden a una realidad pretérita, el carácter de histórico.

El objetivo es, en ese marco, cuestionar el espacio enunciativo del cine documental que, por convención, está abocado a representar fílmicamente lo real y posee una enorme vocación referencial. Para tal efecto se analiza un tipo particular de cine, el documental de compilación, para contrastarlo con la "operación histórica", según la caracterizó Michel de Certeau (1999) como una combinación entre determinado lugar social, ciertas prácticas científicas y una modalidad de escritura, intentando iluminar tanto el campo cinematográfico como el historiográfico. En el caso de ambos, la guía reflexiva es la cuestión del documento, el trabajo de archivo -que comprende institución, repertorio de documentos, prospección y búsqueda- y cuáles son las modalidades para incorporar aquel como insumo de un determinado discurso que explica el pasado.

El vínculo existente entre el cine y la disciplina histórica fue examinado por Robert Rosenstone (1997). Éste planteó que, a diferencia del siglo XIX, cuando los historiadores delinearon el carácter profesional de su quehacer, y tanto ellos como la sociedad europea contaban con la literatura como referente explicativo, durante el siglo XX ese lugar fue ocupado por el cine. En el mundo occidental, según Rosenstone, la anterior prerrogativa de la imaginación literaria vivió una crisis progresiva y, desde mediados de la centuria cuando menos, ha sido la imagen-movimiento la encargada de esbozar los imaginarios, ordenar las tramas que se generan en el seno de la cultura popular masiva y proveer un conjunto -no siempre homogéneo- de representaciones sociales y códigos morales (63-64).

$\mathrm{Si}$ al cine agregamos las proteicas manifestaciones de los distintos formatos audiovisuales hoy día existentes, es posible advertir cómo desde la industria cultural se construyen nociones comunes sobre la historia y lo histórico. Estas pueden ir a favor o mostrarse contrarias al sentido 
común histórico difundido socialmente, que a su turno refuerza o a veces desestabiliza la producción de los historiadores dentro de los marcos disciplinares. Los canales de distribución cinematográfica desempeñan a tal efecto una tarea trascendental, con un alcance en cuanto a tamaño de audiencia muchísimo mayor que la historia académica, pero además con unos patrones bien definidos respecto a las cintas que la misma industria conceptúa como de temas o personajes históricos.

Al respecto, habría que recordar que aquello que Marc Ferro (1995) denominó "visión fílmica de la historia" (190), fue posible luego de la creación de una serie de códigos y una verdadera estética para dar cuenta del pasado. Un paso significativo en la producción mercantil de las imágenes en movimiento y su diseminación a escala planetaria fue, en tal camino, la invención del montaje, concebido como yuxtaposición de dos o más planos rodados en instantes distintos y que, sucediéndose frente a los ojos del espectador, adquieren determinado sentido según el contexto enunciativo de la cinta. Debemos recordar que el cine, en efecto, se articula con imágenes fragmentarias. Esto, que para Antonio Weinrichter (2009) constituye una "discontinuidad esencial", ha tenido en el montaje un modo de superarse con creces para hilvanar discursos, a pesar que "la tradición del montaje ha consistido en disfrazar la violencia de su propia operación, para ofrecer una apariencia sin fisuras de continuidad" (54).

Considerando a quienes elaboran un discurso sobre la historia y a quienes lo reciben, François Niney afirmó que se debe asimismo tener en cuenta que el cine, en cuanto invención de los albores del siglo XX trastornó "el orden de las representaciones; es decir, la relación sujeto/ objeto, hombre/mundo, imaginario/realidad" (24). El decurso del llamado "cine de los primeros tiempos" asistió a una permutación de las expectativas puestas en el cinematógrafo. El invento y sus artífices oscilaron, según el mismo autor, entre la ciencia y el espectáculo de barraca, entre la avidez por registrar el movimiento y "captar la naturaleza en vivo, transmitir la sensación del movimiento real y de la vida, producir verdaderos retratos vivientes" (53), por cuanto las distinciones o la separación de esferas entre el documental y la ficción merecen ser repensadas desde un campo específico.

El cine de compilación se presta a ello porque ofrece una serie de particularidades. Corresponde a cintas documentales cuyas imágenes provienen, en su totalidad o mayoritariamente, de secuencias fílmicas 
pre-existentes. Los realizadores, para dar cuenta de determinado asunto, no graban material nuevo en el presente, sino que recurren a otros films, ya sea propios, o, tanto más usual, ajenos, así como también a repositorios de imágenes o películas. Por este motivo la búsqueda en los archivos fílmicos adquiere un valor inigualable, ya que provee materiales para la operación primordial de este tipo de cine, el montaje (de donde provienen otras denominaciones con las cuales se conoce: film de montaje, film de archivo o cine de found footage o metraje encontrado).

La compilación es un procedimiento recurrente en el campo cinematográfico, con el cual estamos familiarizados a partir de los documentales educativos y de divulgación. A diferencia de cuanto acontece con el cine de ficción, en la tradición documental la recurrencia al found footage "se estableció como un elemento integral de exposición y argumentación, sirviendo a menudo de ilustración de una referencia verbal o como medio de rellenar brechas en la continuidad espacial o la evidencia didáctica", de acuerdo con Paul Arthur (58). Esa familiaridad puede hacer olvidar que aquella es un proceso complejo, donde opera la sintaxis de imágenes en movimiento para re-semantizar cuadros o secuencias mayores e integrarlos en un nuevo contexto enunciativo. Compilar se vinculó en su origen a la invención del montaje durante el cine de los primeros tiempos y su conceptualización por parte de los cineastas soviéticos y de las vanguardias de las primeras décadas del siglo XX, teniendo un uso propagandístico sistemático a partir de la Primera Guerra Mundial.

El historiador y cineasta estadounidense Jay Leyda (1964) fue uno de los primeros en estudiar en profundidad el desarrollo de este tipo de film. Leyda se inclinó por denominarlo cine de compilación, ya que de tal manera se identifica la etapa durante la cual se elabora el discurso fílmico: es en la mesa de edición donde las imágenes en movimiento adquieren un nuevo significado (9). Extraídas de su contexto enunciativo original, son utilizadas por un director o un montajista como piezas de un nuevo discurso y, en tanto discurso sobre lo real (estatuto atribuido al cine documental), su carga demostrativa tiene un peso que parece incontestable.

Este mecanismo de apropiación y re-significación propicia, según Leyda,

la capacidad de comunicar por medio del cine argumentos complejos 
e ideas abstractas. Un film así concebido puede, en consecuencia, mucho más que relatar una cierta narración o mostrar, situando en la pantalla, determinados personajes o elementos. El uso de la compilación con fines propagandísticos demostró que los distintos componentes del lenguaje fílmico (luz y color, sonido, diálogos, inter títulos, etc.), pueden orientarse a entregar un mensaje de alto contenido ideológico, un verdadero "cine de tesis" (65). Siguiendo a Pudovkin, para quien el sentido informativo del documental de compilación difería "del noticiero fílmico en igual medida que un editorial o un artículo periodístico difiere de las noticias dispuestas en la siguiente columna", Leyda apuntó que directores y montajistas lograban impactar a través de "interrelaciones directas entre aquello que parecerían hechos sin relación desperdigados en el tiempo y el espacio" (66).

Paul Arthur (1999) resumió las dos formas contrastantes en que la teoría fílmica y los practicantes del oficio cinematográfico conciben el problema. Por una parte, una postura que sostiene que las imágenes de archivo, incluidas las "vistas" del cine de los primeros tiempos, los noticieros cinematográficos y las imágenes de lo real de las tecnologías posteriores, son portadoras de información "cruda" sobre la realidad, que adquiere un significado en manos de un emisor capaz de situarlas en un marco enunciativo con cierta lógica. Por otra parte, quienes ven en la apropiación de imágenes encontradas un gesto político, definido por el intento de cuestionar los significados ideológicos inherentes a la producción original de esas imágenes, es decir, del tiempo histórico cuando fueron rodadas con la intención de registrar un acontecimiento en particular. En este sentido, agrega Arthur, la compilación realizada con metraje encontrado "es, por definición, una operación dialógica, que enfrenta dos (o más) agentes enunciativos entre sí" (62).

Puede apreciarse que las similitudes con la labor historiográfica son sugerentes. Además del gesto de la búsqueda en archivos (cuestión que, de nuestro lado de la disciplina, merece una mayor lectura crítica), se encuentra la tarea de más vasto alcance de hilvanar con los materiales ahí espigados una explicación coherente sobre el pasado. Esta debe ser acorde a los requerimientos de cada campo de actividad, recordando que el cine y la historia son practicados desde lugares sociales disímiles, pero que, en tanto discursos social y culturalmente creados, aran un terreno común, el de la experiencia histórica registrada en distintos soportes, cuyos vínculos referenciales con la realidad también han sido sancionados socialmente. 
Sobre el particular, el resultado de la investigación de los historiadores se acerca más al del cineasta de compilación que a otras variedades de cine documental, donde generalmente la intervención de los realizadores sobre la actualidad o la información presentada son objeto de escamoteo. Por el contrario, "todos los recursos por medio de los cuales el espectador es persuadido de contemplar imágenes familiares como si no las hubiera visto con anterioridad, o a través de los cuales la mente de éste se vuelve más alerta sobre el sentido más amplio de materiales antiguos, tal es el propósito de la verdadera compilación" (45).

Se avizora aquí una concordancia con la escritura histórica, que erige su decir respecto del pasado sobre una documentación relegada al pie de la página. En palabras de Michel de Certeau (1999), "una mitad, continua, se apoya sobre otra, diseminada para poder decir lo que significa la otra sin saberlo" (110). Desde la óptica crítica del historiador francés, la producción académica sobre el devenir de las sociedades se funda en la propia institucionalización de sus practicantes, quienes no parecen advertir con certeza cuál es la función que, en términos discursivos, lleva a cabo el material de archivo. Éste "desempeña el encargo de acreditar el discurso: como es referencial, introduce cierto efecto de lo real; y por su fragmentación, nos remite discretamente a un lugar de autoridad", en virtud de lo cual los documentos o fuentes de diversa naturaleza que solemos utilizar, sostienen un discurso que "funciona como una máquina que obtiene de la cita una verosimilitud para el relato y una convalidación del saber; produce, pues, la confiabilidad" (110).

En la vereda cinematográfica, los documentales de compilación más conocidos han alentado de forma semejante una apuesta por generar conocimiento respecto del pasado. Por definición, y en la medida en que el dispositivo fílmico provee materiales de archivo, ese pasado es el del siglo XX y no puede remontarse más hacia atrás en el tiempo (y en cambio sí puede recoger la iconografía más reciente, vuelta más proteica con los cambios tecnológicos y las posibilidades de reproducción y difusión exponencial de imágenes de las últimas dos décadas). El historiar de los cineastas que han incursionado en la compilación tiende a ser interesado o comprometido, más apegado al tiempo pretérito -reciente y acucianteque el acercamiento que trasuntan muchos historiadores académicos. Conocer el pasado resulta posible, en la apuesta fílmica, gracias a una nueva observación de aquello que ya fue observado-registrado por la cámara y, en algunas ocasiones, observado también por los espectadores 
de las cintas originales. Tal materia prima es susceptible de tramas distintas, orientadas a interpretaciones del pasado igualmente distintas y con matices que pueden variar según la sensibilidad, las capacidades expresivas y la voluntad de comunicar un mensaje por parte de los cineastas. Aquello puede quedar más claro si se contrasta el acercamiento poético de La noche y la niebla (Alain Resnais, 1955), uno de los primeros films que mostró los campos de concentración nazi, con el enfoque político directo de Morir en Madrid (Frédéric Rossif, 1962), abiertamente en contra de la dictadura franquista, o con la ironía con la que se asiste, desde las pantallas de televisión, a la caída de Ceaucescu en Videogramas de una revolución (Harun Farocki, 1992).

En el caso de La Spirale, la motivación para realizar el film fue también un pasado acuciante, en algún grado casi indistinguible del presente. Sus artífices habían estado comprometidos con el proceso de la Unidad Popular chilena desde sus respectivos campos de actividad y el golpe militar de 1973 impuso suma urgencia al mensaje que podría vehicular una película hecha de múltiples películas.

La Spirale, film de compilación

De acuerdo con los créditos que exhibe la cinta, La Spirale fue dirigida por Armand Mattelart, Jacqueline Meppiel y Valérie Mayoux. Los realizadores contaron con fondos franceses y, tanto o más fundamental, la colaboración de Chris Marker. Este fue el principal impulsor del proyecto en su dimensión de pieza de controversia política y, asimismo, quien delineó los resultados del mismo como pieza fílmica.

La figura consular de Chris Marker fue clave en la realización de la cinta. Según el propio Mattelart, el cineasta galo -quien había estado en Chile en 1972- coordinó todo para que el productor Jacques Perrin consiguiera los apoyos financieros para el proyecto en Francia. Antes de concretarse, Marker articuló también al equipo realizador, presentándole al sociólogo belga a Jacqueline Meppiel y Valérie Mayoux. Estas dos últimas eran, según indicó Mattelart en una entrevista el año 2009, "dos montadoras que habían trabajado con [Marker] en varias películas políticas" (3). Muy en su estilo, "una vez conformado ese equipo de realización, Marker se eclipsó. Volvió en la fase final para la elaboración y la inserción del comentario en off' (Mattelart y Bigo 3). La Spirale abreva por tanto de la poética de Marker en cuanto a su propuesta fílmica, donde sobresale el acto de la compilación, la centralidad otorgada al montaje 
y cierta atención que adquieren las imágenes en movimiento en tanto dispositivo de observación de lo social y generadoras de un régimen visual respecto del tema que presentan. Esto, a pesar de que aquello que el documental en cuestión busca entregar con meridiana claridad es un mensaje político, cuestión que logra y engrana asimismo con la postura ideológica del cineasta francés y su manera de entender la práctica del cine.

La cinta desarrolla una explicación de la derrota del proyecto de la Unidad Popular centrada en el adversario. A lo largo de sus 140 minutos de duración, La Spirale expone de qué manera la derecha chilena logró formar grupos de choque y un movimiento de amplia convocatoria desde 1970, para disputar el espacio público a las clases populares organizadas en su propio terreno político. Es decir, con propiedad podría insertarse en el llamado cine de tesis, con una interpretación de la historia reciente de Chile bastante clara. Desde un inicio, afirmó Mattelart, "el proyecto de la película era mostrar de qué manera los diversos actores que componen el frente unido de las derechas descubren su propia 'línea de masas' y se aplican a sí mismos las enseñanzas de Lenin: sabotaje de la producción, huelga general, tomas de edificios, manifestaciones callejeras, etc." (4). No era algo inédito como interpretación de la reciente debacle democrática en Chile, pero el atractivo del documental fincó en su modo de presentar el problema, exponiendo las relaciones entre los diversos actores sociales y políticos como parte de un juego de tablero. Este hilo conductor de la cinta muestra las únicas secuencias rodadas exprofeso por el equipo de realizadores, quienes, por el contrario, decidieron utilizar para el grueso del film "materia prima ya existente" (3), proveniente de numerosas secuencias audiovisuales que otorgan sustento al mismo.

Los directores estaban al tanto de que había un gran caudal de imágenes sobre el país desde 1970 hasta 1973 (Mattelart y Bigo 5). Si bien no era el área de actividad preferente del sociólogo, sus varios años de residencia en Chile y sus estudios pioneros sobre la comunicación y los medios masivos como agentes culturales y herramientas ideológicas, eran colindantes con la cinematografía del período. Valérie Mayoux, por su parte, venía de participar, también como montajista, en el documental Septembre chilien (B. Muel y T. Robichet, 1973). En tanto, Jacqueline Meppiel, quien había editado Angela Davis: Portrait of a Revolutionary (Y. DuLuart, 1972) continuaría con posterioridad una carrera prolongada en el mismo ámbito en Cuba. Ambas cineastas habían colaborado con 
Marker en la cooperativa fílmica SLON, que efectuara desde Francia varios documentales comprometidos con los intereses de los trabajadores (Mattelart, 2013: 15)

Se aprecia en la superficie de La Spirale que los realizadores recuperaron varios films chilenos relativamente conocidos (El primer año [1971] y La respuesta de octubre [1972], de Patricio Guzmán, por ejemplo), así como otros, de procedencia extranjera, cercanos políticamente. Aquello demandó un trabajo intenso de búsqueda en archivos, efectuado en grandes depósitos audiovisuales. Algunos de estos fueron las televisiones belga y francesa, cinematecas estadounidenses y, en especial, el Instituto Cubano de Artes e Industria Cinematográficas. A este último habían ido a parar copias de prácticamente todo cuanto se rodó en Chile entre 1970 y 1973, merced a los vínculos establecidos por cineastas de ambos países durante esos años. El trabajo de rastreo y recopilación de imágenes en tales repositorios permitió, en palabras de Mattelart, sistematizar materiales emanados de tres fuentes diversas. La primera, "lo que había filmado la izquierda latinoamericana. La segunda fuente fueron los cineastas norteamericanos y europeos que se habían apasionado por la experiencia chilena [...]. Y la tercera fuente fueron los archivos de las televisiones, de las grandes agencias de prensa o audiovisuales, tales como UPI o Visnews. La televisión pública belga y francesa también filmó el Chile popular. Esas secuencias fueron fundamentales para nosotros" (Mattelart y Bigo, 2009: 5).

En el proceso de trabajo de Mattelart y su equipo se advierten varias similitudes con la labor de generación del conocimiento histórico de parte de los historiadores. Estas parten por la construcción de un acontecimiento histórico (alejado de una noción positivista de acontecimiento) y la capacidad de delimitar e identificar cuáles son los actores implicados. Afirma Antoine Prost (2001) que "el historiador recorta un objeto particular dentro de la urdimbre episódica e infinita que es la historia. Pero esa elección tiene mayores implicaciones, constituye los hechos como tales. El hecho aislado no existe. Es al estudiarlo cuando lo aislamos, a la vez que lo construimos como hecho particular, bajo un aspecto concreto" (245).

Las similitudes de un film como el aquí analizado con la historiografía tienen más dimensiones que compartir. Entre ellas se incluye también la generación de un relato explicativo -confeccionado con imágenes- 
donde la causalidad se confunde con el devenir temporal. Dicho relato, verdadero guión cinematográfico que concretó la premisa documental de Mattelart, Mayoux y Méppiel, supuso la redacción de un texto, distinto de aquel escrito con posterioridad para la voz en off que escuchan los espectadores. Dentro de este marco conceptual, las imágenes de archivo aportan el valor de prueba. Con mayor fuerza incluso que en el caso de la historiografía, las secuencias de La Spirale, en tanto compilación, corporeizan a los actores del discurso histórico y remiten su verosimilitud a una instancia exterior al propio emisor del discurso.

Se derivan dos problemas de aquí. En primer término, se debe considerar que la operación compilatoria de un documental como La Spirale es tributaria del archivo, pero puede también convertirse eventualmente ella misma en archivo, ya que recolecta y agrupa una serie de fragmentos fílmicos que, de otra forma, pueden muchas veces extraviarse, destruirse, o en último caso permanecer desconocidos desde la posteridad. Esta potencialidad del documental de compilación no desconoce que, como indica David Wood (2009), su materialización depende de entidades mayores de naturaleza similar, organismos como las filmotecas y otros reservorios de imágenes que son lugares de memoria institucionalizados.

Un segundo problema atañe al valor probatorio de las imágenes de archivo, pensado siempre en paralelo con el carácter empírico que, para sus propósitos, obtienen los historiadores de sus indagaciones en los repositorios documentales. En el caso del tipo de cine aquí analizado, ese valor es engañoso, porque está determinado en gran medida por el Modo de Representación Institucional, que Burch (2011) describió como la forma considerada correcta -por la industria fílmica- de construirse una película y, complementariamente, la constitución de un sistema de significados erigido en lenguaje visual. A ello se agregan las atribuciones ontológicas de los dos grandes dominios cinematográficos (documental, cine de lo real y argumental, cine de lo imaginario), cuyas distinciones convencionales han sido muy cuestionadas y presentan una porosidad muy alta, tanto como unos límites bastante difusos (Weinrichter, 2005: 15). Con todo, tratándose de discursos elaborados con imágenes preexistentes, "encontradas", donde la dislocación del sentido original de ellas las vuelve objetos concretos, según indica Antonio Weinrichter (2009), "la imagen apropiada no pierde del todo su valor semántico (representacional o referencial, según se trate de material de ficción o 
documental), lo que la convierte en una imagen históricamente concreta, una imagen dialéctica en el sentido benjaminiano" (50).

En el caso de La Spirale, afirma Mattelart, "las secuencias que provienen de múltiples fuentes fueron retocadas", en la medida en que "no se mantuvo el montaje original. Fue 'deshuesado', desmontado. A tal punto, que a veces resulta difícil reconocer su vinculación original. Tanto más que al ser insertadas en otro contexto narrativo que el que dio origen a su producción y exhibición, cambian por sí mismas de sentido" (Mattelart y Bigo, 2009: 9). Ahora bien, en el film en cuestión, las imágenes de archivo (secuencias de imágenes en movimiento e inserciones de imágenes fijas) no colman todo el metraje de la cinta. El hilo conductor, se recordará, es un juego de tablero. Las fichas y personajes que lo animan crean una representación de las relaciones existentes entre los actores sociales y políticos durante el Chile de 1970 a 1973. Esta fue la modalidad, la "forma cinematográfica" escogida por los realizadores para dar cuenta de la explicación histórica que intentaban comunicar, con cierto nivel de abstracción y esquiva, tal vez, para ser expresada en términos puramente visuales (con meras citas, diríamos, si fuese un texto historiográfico); dificultad que justifica asimismo la presencia constante de un texto que se presenta como comentario-relato verbal que guía al espectador.

Desde el punto de vista de los film studies y los propios cineastas, se ha resaltado que una compilación efectiva debe estar atenta a la producción original de imágenes y cuál es la naturaleza de éstas. Laurent Véray (2003) planteó que hay dos tipos de documentales históricos basados en archivos: "Por una parte, el documental clásico que ha privilegiado siempre la acumulación de planos sin preocuparse demasiado por su origen exacto ni por su sentido real [...]. Por otra, una forma de escritura documental que, opuesta a la anterior, renuncia a la búsqueda ilusoria de la objetividad total" (3). De acuerdo al mismo autor, uno y otro tipo de documental compilatorio descansan sobre maneras disímiles de concebir la historia. El primero, argumenta, como el discurso positivista, "intenta dar cuenta de la historia según una trama événementielle y cronológica, a partir del ensamblaje de imágenes 'que representan lo real' o, al menos, que pueden dar tal apariencia" (3). Mientras, el segundo, "cercano a la investigación histórica moderna (desarrollada después de la Escuela de Annales), se elabora desde una perspectiva crítica, en particular respecto a las imágenes montadas y de aquello que éstas son llevadas a significar de manera evidente o subyacente. De tal forma, el documentalista, tal 
como el historiador, aunque con medios de significación diferentes, toma la distancia necesaria para interrogarse sobre la construcción de su tema y los principios de inteligibilidad de lo real que pone en práctica" (4).

Según Weinrichter (2009), para la vanguardia artística del siglo XX y los documentalistas más avezados, el verdadero cine de compilación no esconde, sino que vuelve evidentes las operaciones de apropiación y reescritura fílmicas (55). Agrega el mismo autor que tanto el planteamiento del director como su interpretación del problema tratado afloran en las suturas del montaje, que en consecuencia deben hacerse visibles y explícitas, no escamoteándolas de la atención de los espectadores al presentarles un discurso con apariencia de naturalidad (60). De esta forma se propicia un cuestionamiento de la "operación cinematográfica", volviendo patente su institucionalidad por medio de un discurso fílmico reflexivo que alerta en todo momento sobre la construcción social y cultural de las imágenes.

Si hubiera que emparentar La Spirale con el cine político que contemporáneamente se realizó en América Latina, la filiación no resulta obvia. Durante las décadas de 1960 y 1970, los documentales rodados por los cineastas latinoamericanos se inscribieron en los "nuevos cines" del continente. La tendencia preponderante aquí fue la utilización del registro directo, con la intención de documentar -cámara en mano- los problemas sociales y políticos de la región en el presente. La cámara era así testigo en el propio lugar de los acontecimientos y aportaba evidencia iconográfica que desvelaba aquellas imágenes edulcoradas construidas desde otras coordenadas ideológicas (Burton, 1990).

Junto con lo anterior, los documentalistas latinoamericanos no recurrieron tanto a la compilación, cuanto al collage. Sobresale al respecto la creación de alto vuelo del cubano Santiago Álvarez, quien por medio de animaciones, sobreimposiciones y otros recursos visuales, reelaboró la superficie del plano cinematográfico, logrando entregar un mensaje muy claro con procedimientos bastante sofisticados en cuanto atañe a la constitución del signo (Ortega, 2009).

Desde una y otra estrategia fílmica, sin embargo, puede plantearse la existencia de cierto terreno compartido con una compilación como $\mathrm{La}$ Spirale, en su ánimo de cuestionar el lenguaje audiovisual preponderante y su modo recurrente para construir en pantalla la realidad de América Latina. Aquello era justamente el aspecto del imperialismo cultural que, 
desde el cine, se intentaba combatir, aduciendo la penetración de éste y los referentes hollywoodenses que habían alienado las audiencias locales por varias décadas, a lo que se agregaba los medios de entretención y comunicación impresos y, más recientemente, la televisión, áreas que el propio Mattelart había estudiado con detenimiento en Chile.

Resulta interesante constatar que, al menos en cuanto toca al desarrollo contemporáneo del cine documental estadounidense, según Paul Arthur (1999), el inusitado interés por las secuencias fílmicas de archivo se debió a dos fuerzas entrelazadas, "el deseo de reformular los tropos de la narrativa histórica, y la crítica micro-política respecto a la exclusión histórica llevada a cabo por sectores desafectos en el terreno del modo de representación dominante" (60). La indagación en la realidad y el devenir social se constituyó, en consecuencia, en un ejercicio que partía por reconsiderar las propias coordenadas de observación.

Imágenes del pasado y escritura fílmica

Jay Leyda (1964) puso de relieve que una característica definitoria del cine de compilación era su capacidad para utilizar las imágenes del enemigo en su propia contra. En la medida en que vehicula una tesis o determinada interpretación explícita sobre los hechos o personajes que presenta, un documental de compilación puede, en efecto, tomar imágenes rodadas originalmente con un fin propagandístico, enaltecedor o meramente informativo y, puestas en un nuevo guión explicativo, invertir totalmente sus designios originales.

Tal operación sobre el sentido de las imágenes, Leyda llegó a establecerla como una constante del ejercicio compilatorio, al trazar la genealogía de la modalidad documental en cuestión. El caso en cierto modo inaugural y uno de los más notables fue La caída de la dinastía Romanov (1927), donde la directora Esfir Schub recogió fragmentos de cintas de 1912 a 1917 de la corte zarista y, al volverlos a montar, denunció la vacuidad de la clase gobernante durante el régimen depuesto y la distancia que exhibía con respecto al pueblo ruso (Leyda 24-26). Después de ese trabajo paradigmático, una voluntad semejante de re-utilización de las imágenes en movimiento en la arena ideológica se verificó en numerosas latitudes, sobresaliendo la batalla propagandística durante la Segunda Guerra Mundial y, finalizada ésta, la apropiación que los aliados -particularmente los estadounidenses- hicieron de los materiales rodados por los nazis. 
En La Spirale abundan pasajes en que el discurso de los realizadores se apropia de la producción audiovisual de los enemigos para volverlas en su contra, como recalcara el crítico Serge Toubiana (1976) cuando aquella se estrenó (57). Y aquello ocurre a nivel del intercambio mundial de imágenes, en consonancia con el acontecimiento histórico de alcance igualmente mundial que constituyó la experiencia de la Unidad Popular chilena y el golpe de Estado. Así, comparecen escenas extraídas de documentales estadounidenses sobre la instrucción ideológica dada por Washington a militares y sindicalistas en América Latina. Hay también imágenes televisivas provenientes de la presentación a la prensa de la junta militar de gobierno, en 1973. Se utiliza, además, secuencias de reuniones sociales de altos oficiales de las fuerzas armadas golpistas, entre otras.

Si se considera incluso el espectador implícito de un documental como La Spirale, resulta indudable que éste debe contar, antes de enfrentarse a las imágenes en la pantalla, con un determinado conocimiento del tema que desarrolla la película. Más específicamente, indica Toubiana, tal espectador "tiene al respecto cierto número de informaciones que le ha sido proporcionado por los medios masivos" (57). El aporte de la compilación documental, en un caso así, es la posibilidad de efectuar un análisis profundo y detallado, estableciendo relaciones entre elementos antes desperdigados.

Según recalca CarolinaAmaral deAguiar(2011), la re-contextualización de esas imágenes funge en La Spirale como testimonio en contra de los conspiradores. La cinta de Mattelart y su equipo presenta una tesis del decurso histórico del pasado reciente de Chile, sustentada en una serie de evidencias que autoriza a los realizadores para argüir sus posiciones en un tribunal de la opinión pública internacional. Y, en ese sentido, el documental recurre asimismo a imágenes fijas de diversa procedencia, junto con todo el material de secuencias extraídas de otros films (242244). Se trata de un mecanismo retórico que, como aseveró Toubiana, "consiste en encontrar, para una idea, para toda noción que corrobora el análisis, un plano, una huella, algún elemento de la realidad que permita legitimarlos" (57).

Es pertinente retener este gesto de búsqueda y selección de materiales si se quiere pensar el problema desde la vereda historiográfica. ¿Qué hacemos los historiadores en el archivo? Inmersos en los fondos 
documentales, ¿nos acordamos de cuestionar la distancia que media entre esos papeles del ayer y nuestra escritura en el presente? A ello se añade una semejanza más con los editores en la mesa de montaje. Afirma Steedman (2002) que, en buena medida, los historiadores nos dedicamos a leer documentos que no fueron pensados para ser vistos por nosotros (30). Ese aserto es ajustado para la inmensa mayoría de la producción histórica profesional, cuyo trabajo de indagación en el archivo se desarrolla en depósitos que resguardan una memoria institucional con fines burocráticos y no de introspección de las instituciones o sus personeros. Tales documentos, originados con un fin específico en su tiempo (y poseedores por tanto de ciertas coordenadas discursivas que deben ser elucidadas), son exhumados desde el presente para extraer de ellos información muy disímil, a contrapelo incluso de su naturaleza original.

En tal sentido, la convergencia de la práctica histórica y el cine de compilación es significativa. "Ciertamente las tomas preexisten archivadas en alguna parte, pero es claramente la pregunta del cineastahistoriador la que va a determinar la selección, la toma de muestras, y a extraerle un sentido; es decir, asignarle un rol documental", apunta Francois Niney (2009: 388). Sin embargo, el uso que de aquellas se hace en un film compilatorio debe atender necesariamente a las intenciones originales de quienes las rodaron. Es habitual sentirse compelidos por la carga referencial de determinadas secuencias y creer que, en la medida en que provienen del pasado, acreditan la existencia de algo real, de manera tal que el espectador aspire a convertirse en un testigo de la historia. Pese a ello, de forma similar a la crítica a la que los historiadores someten sus fuentes, un documental que reelabora imágenes previamente filmadas debe explicitar la carga ideológica existente en los materiales originales, el aspecto de representación con respecto a lo filmado que ellos ayudaron a elaborar.

Laurent Véray (2007) se ha preguntado sobre el particular si puede pensarse una reflexión histórica efectuada con archivos fílmicos. Si consideramos que las imágenes no son un simple banco de secuencias referenciales o que atestiguan que "eso estuvo ante una cámara", se concluye por necesidad que en la producción de aquellas intervienen lógicas propias que necesitan comprenderse y explicarse antes de integrarlas en otro discurso, donde adquirirán una función diferente y 
subordinada a un mensaje mayor. Por su parte, Niney (2009:389) advirtió que ese cuestionamiento desempeña en el cine de compilación una verdadera crítica del documento, a partir de la cual los realizadores forjan una cierta distancia con las imágenes que reutilizan, acto que contribuye a la recepción de su propio mensaje de parte de los espectadores.

Un problema final derivado del carácter de cine político de La Spirale puede abrir otro género de reflexiones que aquí sólo se alcanza a esbozar. Los realizadores del film, rememoró Mattelart (2013), concibieron su documental como una herramienta ideológica y propagandística pensando generar apoyo para la causa de la resistencia chilena a la dictadura. Tanto Mattelart como Marker estuvieron comprometidos con el proyecto de la Unidad Popular, y tanto el uno como el otro conocían la elocuencia de las imágenes para sustentar sus posturas sobre el quiebre democrático. Decidieron, en consecuencia, elaborar una lectura del pasado reciente de Chile que no cuestionara al gobierno ni los partidarios de la U.P., sino focalizarla en las estrategias de los adversarios: la derrota no provendría de errores o indecisiones propias, sino de la capacidad de los sectores dominantes para movilizar sus recursos y efectuar alianzas (dentro y fuera del país). Tal decisión afecta, por supuesto, la manera en que las imágenes reutilizadas fueron dispuestas en la cinta. Por una parte, aquello era un mensaje para la opinión pública francesa y una propuesta analítica sobre un escenario político similar, de posible alianza de los partidos de izquierda galos (Aguiar, 2013: 56).

Por otra, esa misma decisión y sus alcances en cuanto a la explicación histórica que entrega $\mathrm{La}$ Spirale, inducen a pensar que las imágenes por sí solas no son omnicomprensivas. Es decir, que si bien las secuencias de imágenes en movimiento tienen un gran impacto, dada su carga denotativa y la información referencial que entregan, su significado último depende del tipo de discurso en que son insertas. Esto, que puede parecer muy obvio, no lo es tanto cuando se constata que, en el gremio historiador, hay quienes sostienen aún que los documentos son capaces de hablar por sí solos, sin la necesidad de un observador que los interpele desde el presente. 


\section{Bibliografía}

Aguiar, C. A. de. "Cinema e História: documentário de arquivo como lugar de memoria". Revista Brasileira de História 31(62): 235-250.

Aguiar, C. A. de. "El ímpetu revolucionario latinoamericano en el discurso cinematográfico de Chris Marker". En R. Green e I. Pinto (Eds.). La zona Marker. Santiago: Ediciones Fidocs, 2013. 49-60.

Arthur, P. “The Status of Found Footage”. Spectator 20.1 (1999 - 2000). 57-69.

Burch, N. El tragaluz del infinito (Contribución a la genealogía del lenguaje cinematográfico). Séptima Ed. Madrid: Cátedra, 2011.

Burton, J. (Ed.). The Social Documentary in Latin America. Pittsburgh: University of Pittsburgh Press, 1990.

Certeau, M. De. La escritura de la historia. México D.F.: Universidad Iberoamericana, 1999.

Ferro, M. Historia contemporánea y cine. Barcelona: Ariel, 1995.

Leyda, J. Films Beget Films. A study of the compilation film. New York: Hill and Wang, 1964.

Mattelart, A. "La espiral vuelve a casa". Le Monde Diplomatique 144. Edición chilena, (Sept. 2013): 14-18.

Mattelart, A. y Bigo, D. La espiral. Entrevista. Cultures \& Conflits [En ligne], Textos en castellano, mis en ligne le 29 août 2009. URL: http:// conflits.revues.org/index17395. html.

Niney, F. La prueba de lo real en la pantalla. Ensayo sobre el principio de realidad documental. México D.F.: Centro Universitario de Estudios Cinematográficos, UNAM, 2009.

Ortega, M. L. "De la certeza a la incertidumbre: collage, documental y discurso político en América Latina". En S. García y L. Gómez (Eds.). Piedra, papel y tijera. El collage en el cine documental. Madrid: Ocho y Medio libros de cine, 2009. 101-137. 
Prost, A. Doce lecciones sobre la historia. Madrid: Frónesis - Universitat de Valéncia, 2001.

Rosenstone, R. El pasado en imágenes. El desafío del cine a nuestra idea de la historia. Barcelona: Ariel, 1997.

Steedman, C. Dust. The Archive and Cultural History. New Brunswick: Rutgers University Press, 2002.

Toubiana, S. "Savoir posthume (La Spirale)". Cahiers du Cinema 265 (1976): 56-60.

Véray, L. "L'Histoire peut-elle se faire avec des archives filmiques? 1895". Mille huit cent quatre-vingtquinze 41 (2003) [En ligne], mis en ligne le 13 février 2007. URL: http: / / 1895.revues.org/266.

Weinrichter, A. Desvíos de lo real. El cine de no ficción. Segunda Ed. Madrid: T\&B Editores, 2005.

Weinrichter, A. “Notas sobre collage y cine”. En En S. García y L. Gómez (Eds.), Piedra, papel y tijera. El collage en el cine documental. Madrid: Ocho y Medio libros de cine, 2009. 37-64.

Wood, D. (2009). "Memorias de una mexicana: la revolución como monumento fílmico". Secuencia 75, (2009): 147-170. 